МежАународный опыт

законодательного регулирования порядка формирования финансовых отчетов микроорганизациями

\author{
Наталья Сергеевна Матвеева \\ E-mail: natalia.matveeva@inbox.ru, ORCID 0000-0002-8353-5638 \\ Научно-исследовательский финансовый институт Минфина России, \\ Москва 127006, Российская Федерация
}

\begin{abstract}
Аннотация
В настоящей статье анализируется опыт законодательного регулирования порядка формирования финансовых отчетов микроорганизациями в странах СНГ, странах Европейского союза, а также в Великобритании. Исследование проводилось на основе анализа законодательных актов указанных стран, национальных стандартов бухгалтерского учета и финансовой отчетности.

В рамках исследования в статье определены критерии отнесения организации к микроорганизации в рассматриваемых странах, проанализированы Аокументы, регламентирующие порядок составления финансовой отчетности, а также проведено сравнение с порядком формирования финансовых отчетов микроорганизациями в Российской Федерации.

Актуальность темы обусловлена ролью микроорганизаций как важной составляющей экономики страны, оказывающей влияние на уровень занятости, валового внутреннего продукта и другие важные показатели развития. В России микропредприятия составляют 96 \% сектора малого и среднего предпринимательства, Аоля которого в валовом внутреннем продукте, по оценкам Росстата, составила 20,6 \% в 2019 г. и которое обеспечило занятость 33 \%. А^я сравнения: в странах ОЭСР малый и средний бизнес создает в среднем около 55 \% ВВП и около 59,1 \% рабочих мест, а в странах Евросоюза цифры еще выше. Увеличение вклада малых и средних предприятий почти полностью происходит за счет микропредприятий, которые составляют 93 \% таких преАприятий. С целью подАержки развития микроорганизаций необходимо создание благоприятных условий Аля осуществления предпринимательской деятельности, в том числе упрощение порядка формирования и подачи финансовой отчетности.
\end{abstract}

Ключевые слова: финансовая отчетность, микроорганизации, стандарты финансовой отчетности, финансовое законодательство, зарубежный опыт

JEL: E62, H83, M48

Аля цитирования: Матвеева Н. С. Международный опыт законодательного регулирования порядка формирования финансовых отчетов микроорганизациями // Финансовый журнал. 2021. T. 13. № 5. С. 125-138.

https://doi.org/10.31107/2075-1990-2021-5-125-138.

(C) Матвеева Н. С., 2021 
https://doi.org/10.31107/2075-1990-2021-5-125-138

\title{
Legislative Regulation Financial Statement Preparation by Micro Entities: International Experience
}

\author{
Natalia S. Matveeva \\ Financial Research Institute, Moscow 127006, Russian Federation \\ natalia.matveeva@inbox.ru, https://orcid.org/0000-0002-8353-5638
}

\begin{abstract}
The article analyzes the experience of legislative regulation of financial statement preparation by micro entities in the Commonwealth of Independent States, the European Union, and the United Kingdom. The legislative acts of the countries, national accounting standards and financial reporting standards serve as the methodological basis for the analysis.

For the purpose of this study the article identifies the criteria for categorizing an organization as a micro entity, analyzes the documents regulating the procedure for the preparation of financial statements, and compares the procedures for financial reports formation by micro entities in different countries. Micro entities are an important component of the country's economy, affecting the level of employment, gross domestic product and other important indicators of the country's development.

In Russia, micro entities account for 96 percent of the small and medium-sized business sector, whose share in the gross domestic product was about $20.6 \%$ in 2019 according to Federal State Statistics Service estimates and which created about $33 \%$ of jobs. For comparison, in the OECD countries small and medium-sized businesses generate, on average, about $55 \%$ of GDP and about $59.1 \%$ of jobs, whereas in the EU countries the percentage is higher: $57.5 \%$ of GDP, and $65 \%$ of the employed.

However, in order to support the development of micro entities, it is necessary to create favorable conditions for the implementation of entrepreneurial activities, in particular through simplifying the procedure for the formation and submission of financial statements.
\end{abstract}

Keywords: financial statement, micro entities, financial reporting standards, financial legislation, international experience.

JEL: E62, H83, M48

For citation: Matveeva N.S. Legislative Regulation Financial Statement Preparation by Micro Entities: International Experience. Financial Journal, 2021, vol. 13, no. 5, pp. 125-138 (In Russ.). https://doi.org/10.31107/2075-1990-2021-5-125-138.

(C) Matveeva N.S., 2021

\section{BВEAEHИE}

Понятие "микроорганизации" (или микропредприятия, микробизнес) и критерии отнесения организации к Аанной категории различаются в разных странах. Это обусловлено экономическими и социальными особенностями развития конкретной страны, а также сложившейся правовой среАы. Критерии могут включать численность работников, объем годовой выручки и другие параметры. При этом если в оАних странах необходимо соответствие всем законодательно установленным критериям, чтобы субъект малого бизнеса относился к категории микропреАприятия, то в Аругих странах необходимо соблюдение, например, только Авух из трех или наибольшего по значению критерия. При этом в некоторых странах, например в Республике Узбекистан, среднегодовая численность работников, являющаяся критерием отнесения предприятия к микроорганизации, различается Аля разных секторов (производственного, сферы услуг, оптовой/розничной торговли и Ар.). В табл. 1 представлены критерии отнесения организации к микроорганизации, применяемые в исследуемых странах. 
Критерии отнесения организации

к микроорганизации в различных странах /

The criteria for categorizing the organization as micro entity

\begin{tabular}{|c|c|c|}
\hline Страна & $\begin{array}{l}\text { Численность } \\
\text { сотруАников }\end{array}$ & $\begin{array}{c}\text { Финансовые показатели и/ияи иные требования } \\
\text { (например, отраслевые) }\end{array}$ \\
\hline $\begin{array}{l}\text { Республика } \\
\text { Беларусь }\end{array}$ & $\begin{array}{l}\text { Ао } 15 \text { человек } \\
\text { включительно }\end{array}$ & - \\
\hline $\begin{array}{l}\text { Республика } \\
\text { Казахстан }\end{array}$ & $\begin{array}{l}\text { Не более } \\
15 \text { человек }\end{array}$ & $\begin{array}{l}\text { СреАнегодовой Аоход не выше тридцатитысячекратного месячного расчет- } \\
\text { ного показателя, установленного законом о республиканском бюджете }\end{array}$ \\
\hline $\begin{array}{l}\text { Российская } \\
\text { Федерация }\end{array}$ & Ао 15 человек & Аоход за год не выше 120 млн руб. \\
\hline $\begin{array}{l}\text { Республика } \\
\text { Узбекистан }\end{array}$ & \multicolumn{2}{|c|}{$\begin{array}{l}\text { От } 1 \text { до } 20 \text { человек в производственном секторе; } \\
\text { от } 1 \text { Ао } 10 \text { человек в сфере услуг и Аругих непроизводственных отраслях; } \\
\text { от } 1 \text { до } 5 \text { человек в оптовой, розничной торговле и секторе общественного питания }\end{array}$} \\
\hline Страны ЕС & $\begin{array}{l}\text { Средняя числен- } \\
\text { ность - } 10 \text { человек }\end{array}$ & $\begin{array}{l}\text { Общая сумма активов по балансу и/ияи чистый оборот - } \\
2 \text { млн евро }\end{array}$ \\
\hline $\begin{array}{l}\text { Велико- } \\
\text { британия }\end{array}$ & $\begin{array}{l}\text { Не более } \\
10 \text { человек }\end{array}$ & $\begin{array}{l}\text { Оборот не более } 632 \text { тыс. фунтов стерлингов за финансовый гоА; } \\
\text { общая балансовая стоимость - не более } 316 \text { тыс. фунтов стерлингов }\end{array}$ \\
\hline
\end{tabular}

Примечание: в Республике Казахстан месячный расчетный показатель - это коэффициент, величина которого устанавливается ежегодно. Согласно Закону Республики Казахстан от 2 Аекабря 2020 г. № 379-VI 3РК "О республиканском бюджете на 2021-2023 годы" месячный расчетный показатель равен 2917 тенге.

Источник: составлено автором на основе анализа законодательства стран / Source: compiled by the author based on the analysis of the legislation of the countries.

\section{ФОРМИРОВАНИЕ ФИНАНСОВОЙ ОТЧЕТНОСТИ МИКРООРГАНИЗАЦИЯМИ}

Микроорганизации ведут бухгалтерский учет и формируют отчетность согласно установменным национальным законодательством требованиям. В табл. 2 представлены данные о применяемых микроорганизациями законодательных актах и стандартах при формировании финансовой отчетности.

Таблица 2

\section{Применяемые микроорганизациями законодательные акты и стандарты при формировании финансовой отчетности / Legislation and standards applied by micro entities in the preparation of financial statements}

\begin{tabular}{|c|c|c|c|c|}
\hline Страна & $\begin{array}{c}\text { Общие требования } \\
\text { к отчетности }\end{array}$ & $\begin{array}{c}\text { Применяемые } \\
\text { стандарты }\end{array}$ & $\begin{array}{l}\text { Упрощенный } \\
\text { формат } \\
\text { отчетности }\end{array}$ & $\begin{array}{c}\text { Особенности } \\
\text { законодательства }\end{array}$ \\
\hline Беларусь & $\begin{array}{l}\text { Закон от } 12 \text { июля } 2013 \text { г. } \\
\text { № } 57-3 \text { "0 бухгалтерском } \\
\text { учете и отчетности" }\end{array}$ & $\begin{array}{l}\text { Национальный стандарт } \\
\text { бухгалтерского учета } \\
\text { и отчетности }\end{array}$ & + & $\begin{array}{l}\text { Можно вести учет в книге } \\
\text { учета Аоходов и расходов } \\
\text { организаций и индивидуаль- } \\
\text { ных преАпринимателей, } \\
\text { применяющих упрощенную } \\
\text { систему налогообложения }\end{array}$ \\
\hline Казахстан & $\begin{array}{l}\text { Закон № 234-III } \\
\text { от } 28 \text { февраля } 2007 \text { г. } \\
\text { "О бухгалтерском } \\
\text { учете и финансовой } \\
\text { отчетности" }\end{array}$ & $\begin{array}{l}\text { Национальный стандарт } \\
\text { финансовой отчетности, } \\
\text { или международный } \\
\text { стандарт финансовой } \\
\text { отчетности (МСФО), } \\
\text { или межАународный } \\
\text { стандарт Аля малого } \\
\text { и среднего бизнеса }\end{array}$ & + & $\begin{array}{l}\text { Согласно национальному } \\
\text { стандарту субъект может } \\
\text { представлять самостоятельно } \\
\text { разработанные формы финан- } \\
\text { совой отчетности, которые } \\
\text { способны улучшить качество } \\
\text { информации, предоставляе- } \\
\text { мой заинтересованным мицам }\end{array}$ \\
\hline Узбекистан & $\begin{array}{l}\text { Закон от } 30 \text { августа } \\
1996 \text { г. № 279-І } \\
\text { "О бухгалтерском учете» }\end{array}$ & $\begin{array}{l}\text { Национальные стан- } \\
\text { Аарты бухгалтерского } \\
\text { учета }\end{array}$ & + & \\
\hline
\end{tabular}




\begin{tabular}{|c|c|c|c|c|}
\hline Страна & $\begin{array}{c}\text { Общие требования } \\
\text { к отчетности }\end{array}$ & $\begin{array}{c}\text { Применяемые } \\
\text { стандарты }\end{array}$ & $\begin{array}{c}\text { Упрощенный } \\
\text { формат } \\
\text { отчетности }\end{array}$ & $\begin{array}{c}\text { Особенности } \\
\text { законодательства }\end{array}$ \\
\hline $\begin{array}{l}\text { Российская } \\
\text { Федерация }\end{array}$ & $\begin{array}{l}\text { Закон от } 6 \text { Аекабря } \\
2011 \text { г. № 402-Ф3 } \\
\text { "О бухгалтерском учете" }\end{array}$ & $\begin{array}{l}\text { Положения по бухгал- } \\
\text { терскому учету }\end{array}$ & + & $\begin{array}{l}\text { Организация может разраба- } \\
\text { тывать формы финансовой } \\
\text { отчетности самостоятельно } \\
\text { при составлении упрощенной } \\
\text { годовой финансовой отчетности }\end{array}$ \\
\hline Эстония & $\begin{array}{l}\text { Закон о бухгалтерском } \\
\text { учете от 20.11.2002 }\end{array}$ & $\begin{array}{l}\text { Стандарты финансовой } \\
\text { отчетности }\end{array}$ & + & \\
\hline Болгария & $\begin{array}{l}\text { Закон "О бухгалтерском } \\
\text { учете" }\end{array}$ & $\begin{array}{l}\text { Национальные стан- } \\
\text { дарты бухгалтерского } \\
\text { учета }\end{array}$ & + & \\
\hline Чехия & $\begin{array}{l}\text { Закон № 563/1991 } \\
\text { "О бухгалтерском учете" }\end{array}$ & $\begin{array}{l}\text { Чешские стандарты } \\
\text { бухгалтерского учета } \\
\text { Аля предпринимателей }\end{array}$ & + & \\
\hline Германия & Торговый кодекс & & + & $\begin{array}{l}\text { Можно подготовить еАиный } \\
\text { пакет отчетности Аля бухгалтер- } \\
\text { ского учета и налогообложения }\end{array}$ \\
\hline Франция & Торговый кодекс & \begin{tabular}{|l|} 
Сборник стандартов \\
бухгалтерского учета Аля \\
составления годовых \\
отчетов промышленных \\
и коммерческих \\
предприятий
\end{tabular} & + & \\
\hline Италия & ГражАанский коАекс & & + & $\begin{array}{l}\text { Соответствие отчетности } \\
\text { международным стандартам }\end{array}$ \\
\hline НиАерланды & ГражАанский кодекс & $\begin{array}{l}\text { ГомманАские стандарты } \\
\text { бухгалтерского учета }\end{array}$ & + & $\begin{array}{l}\text { Право ориентироваться на } \\
\text { требования налоговых орга- } \\
\text { нов при подготовке годовой } \\
\text { финансовой отчетности }\end{array}$ \\
\hline Бельгия & $\begin{array}{l}\text { Кодекс преАпринима- } \\
\text { тельской деятельности } \\
\text { и экономического права }\end{array}$ & $\begin{array}{l}\text { Бельгийские обще- } \\
\text { принятые принципы } \\
\text { бухгалтерского учета }\end{array}$ & + & \\
\hline Греция & \begin{tabular}{|l|} 
Греческие стандарты \\
бухгалтерского учета
\end{tabular} & \begin{tabular}{|l} 
Греческие стандарты \\
бухгалтерского учета
\end{tabular} & + & Ава типа микроорганизаций \\
\hline Португалия & $\begin{array}{l}\text { Закон № 98/2015 } \\
\text { "О коммерческих } \\
\text { компаниях" }\end{array}$ & $\begin{array}{l}\text { Стандарт бухгалтерского } \\
\text { учета Аля микропреА- } \\
\text { приятий }\end{array}$ & + & \\
\hline $\begin{array}{l}\text { Велико- } \\
\text { британия }\end{array}$ & $\begin{array}{l}\text { Закон } 2013 \text { г. о малых } \\
\text { компаниях (отчетность } \\
\text { микроорганизаций) }\end{array}$ & $\begin{array}{l}\text { Стандарт финансовой } \\
\text { отчетности Аля микро- } \\
\text { предприятий FRS } 105\end{array}$ & + & \\
\hline
\end{tabular}

Источник: составлено автором на основе анализа законодательства стран / Source: compiled by the author based on the analysis of the legislation of the countries.

\section{ФИНАНСОВАЯ ОТЧЕТНОСТЬ В СТРАНАХ СНГ}

Общие требования к формированию, представлению и публикации финансовой отчетности в странах СНГ устанавливаются, как правило, законом о бухгалтерском учете и финансовой отчетности, Аетализированные требования устанавливаются национальными стандартами.

Так, согласно закону Республики Беларусь "О бухгалтерском учете и отчетности" все организации обязаны формировать годовую финансовую отчетность ${ }^{1}$. При этом виды отчетов, порядок их составления, а также правила раскрытия информации в индивидуальной

1 Закон Республики Беларусь от 12 июля 2013 г. № 57-3 “О бухгалтерском учете и отчетности». URL: https:// pravo.by/document/?guid $=3871 \& p 0=h 11300057$. 
бухгалтерской отчетности определены в национальном стандарте бухгалтерского учета и отчетности "Индивидуальная бухгалтерская отчетность" ${ }^{2}$.

Закон "О подАержке малого и среАнего предпринимательства" ${ }^{3}$ устанавливает, что с целью подАержки малого и среднего преАпринимательства (микропреАприятия, согласно ст. 3 закона, относятся к субъектам малого предпринимательства) законодательством могут предусматриваться:

- особые режимы налогообложения;

- сокращенный состав бухгалтерской отчетности или освобождение от ведения бухгалтерского учета и составления бухгалтерской отчетности в предусмотренных законоАательством случаях;

- упрощенный порядок преАставления государственной статистической отчетности и Aр.

Таким образом, микроорганизации могут вести бухгалтерский учет и составлять финансовую отчетность на общих основаниях по формам и в порядке, установленным законодательством, мибо вести учет в книге учета Аоходов и расходов организаций и инАивидуальных преАпринимателей, применяющих упрощенную систему налогообложения. В последнем случае микроорганизация освобождается от ведения бухгалтерского учета и составления финансовой отчетности и преАоставляет книгу учета доходов и расхоАов всем заинтересованным сторонам - учредителям или собственникам, государственным и налоговым органам.

В Республике Казахстан общие требования к формированию финансовой отчетности и ее состав устанавливает Закон "О бухгалтерском учете и финансовой отчетности" ${ }^{4}$. Аополнительные требования устанавливаются тремя типами стандартов по решению руководящих органов, утвердивших учетную политику: национальным стандартом финансовой отчетности, межАународными стандартами финансовой отчетности (МСФО) или межАународным стандартом Аля малого и среднего бизнеса. Так, в соответствии с Национальным стандартом финансовой отчетности ${ }^{5}$ финансовая отчетность вкмючает бухгалтерский баланс и отчет о прибылях и убытках.

Учитывая общие требования к финансовой отчетности, субъект имеет право самостоятельно разработать и утвердить в учетной политике применяемые формы финансовой отчетности.

Закон Республики Узбекистан “О бухгалтерском учете» регулирует вопросы составления отчетности. При этом в ст. 1 установлено, что в случае если “межАународными договорами Республики Узбекистан установлены иные правила, чем те, которые содержатся в настоящем Законе, то применяются правила международных договоров". Закон также устанавливает, что "финансовая отчетность субъектами малого и частного преАпринимательства составляется по упрощенной форме» ${ }^{6}$.

Приказ министра финансов Республики Узбекистан “Об утверждении национального стандарта бухгалтерского учета (НСБУ № 20) «Упрощенный порядок веАения бухгалтерского

\footnotetext{
2 Постановление Министерства финансов Республики Беларусь от 12.12.2016 № 104 «Об утверждении Национального стандарта бухгалтерского учета и отчетности “Индивидуальная бухгалтерская отчетность". URL: http://minfin.gov.by/upload/accounting/acts/postmf_121216_104.pdf.

3 Закон Республики Беларусь от 1 июля 2010 г. № 148-3 “О подАержке малого и среднего преАпринимательства". URL: https://pravo.by/document/?guid=3871\&p0=H11000148.

4 Закон Республики Казахстан от 28 февраля 2007 г. № 234-III "О бухгалтерском учете и финансовой отчетности". URL: https://online.zakon.kz/document/?doc_id=30092011.

5 Приказ министра финансов Республики Казахстан от 31 января 2013 г. № 50 "Об утверждении Национального стандарта финансовой отчетности". URL: https://online.zakon.kz/Document/?doc_id=31335042\#pos= 204;-52.

6 Закон Республики Узбекистан от 30 августа 1996 г. № 279-I "O бухгалтерском учете». URL: https://lex.uz/ docs/90764.
} 
учета субъектами малого предпринимательства» ${ }^{7}$ устанавливает, что упрощенный порядок выбирается субъектами малого предпринимательства на добровольной основе.

Годовой финансовый отчет предприятий малого бизнеса состоит из бухгалтерского баланса и отчета о финансовых результатах. Формы финансовой отчетности и правила по их заполнению утверждены приказом министра финансов № $2501^{8}$.

Согласно постановлению кабинета министров Республики Узбекистан “О мерах по сокращению и упорядочению отчетности Аля предприятий малого бизнеса" ${ }^{9}$ отчетность микрофирмы представляют только в органы государственной статистики и налоговые органы на местах по установленным ими формам.

\section{ФИНАНСОВАЯ ОТЧЕТНОСТЬ В СТРАНАХ ЕС}

В Европейском союзе Аиректива 2013/34/EC ${ }^{10}$ от 26 июня 2013 г. нацелена на снижение требований к отчетности и раскрытию информации микропреАприятиями. В АОкументе подчеркивается, что микропреАприятия могут быть освобожАены от целого ряАа обязательств, включая составление отчета об управлении и примечаний к финансовой отчетности. При этом требуемая законодательством информация должна быть преАставлена в пояснениях к балансу. Также микропредприятие может не публиковать ежегодную финансовую отчетность, если содержащаяся в ней балансовая информация Аолжным образом преАставлена согласно национальному законодательству как минимум одному компетентному органу, назначенному соответствующим государством-членом.

МежАународные стандарты финансовой отчетности (МСФО) Аля малых и среАних преАприятий были разработаны Советом по международным стандартам финансовой отчетности в 2009 г. (обновленная редакция была выпущена в 2015 г.) [IFRS, 2015]. В 2013 г. Совет по международным стандартам финансовой отчетности опубликовал Руководство Аля микропреАприятий, целью которого было оказание им поААержки в применении МСФО Аля малых и среАних преАприятий. РуковоАство содержит требования, применимые к микропредприятиям, а также дополнительные указания и наглядные примеры, призванные помочь микропредприятиям применять принципы, содержащиеся в стандарте финансовой отчетности Аля малых и среАних предприятий [IFRS, 2013].

Несмотря на то что в странах Европейского союза можно выделить общие тенденции в Аеятельности микропредприятий и формировании финансовой отчетности, критерии отнесения компании к микропредприятию и законодательное регулирование составления финансовой отчетности во многих странах имеют свои особенности.

В ряде стран (например, Эстония, Болгария, Чехия) закон о бухгалтерском учете является основополагающим, устанавливающим общие требования к финансовой отчетности.

Так, в Эстонии в соответствии с законом о бухгалтерском учете ${ }^{11}$ в конце каждого финансового ГоАа преАприятие АОлЖно Составлять ГОАОвой отчет, КоторЫЙ вКАючает ГОАовой и управленческий отчет. Закон устанавливает, что микропредприятие, которое осуществляет организацию финансового учета и отчетности на основе эстонского стандарта

\footnotetext{
7 Приказ министра финансов Республики Узбекистан № 2501 от 14.08.2013 “Об утверждении национального стандарта бухгалтерского учета (НСБУ № 20) «Упрощенный порядок ведения бухгалтерского учета субъектами малого предпринимательства". URL: https://lex.uz/ru/docs/2222826.

8 Приказ министра финансов Республики Узбекистан от 27 декабря 2002 г. № 140. URL: https://lex.uz/ docs/771825\#2071957.

9 Постановление кабинета министров Республики Узбекистан № 65 от 23.02.2000 «О мерах по сокращению и упорядочению отчетности Аля преАприятий малого бизнеса". URL: https://lex.uz/docs/263115.

${ }^{10}$ Directive 2013/34/EU of the European Parliament and of the Council of 26 June 2013. URL: https://eur-lex. europa.eu/legal-content/EN/TXT/HTML/?uri=CELEX:02013L0034-20141211\&from=EN.

${ }_{11}$ Закон "О бухгалтерском учете» от 20.11.2002. URL: https://www.riigiteataja.ee/akt/13278917?leiaKehtiv.
} 
финансовой отчетности, может подготовить только годовой отчет. Такой отчет согласно стандарту финансовой отчетности Эстонии Аолжен включать как минимум бухгалтерский баланс и отчет о прибылях и убытках, а также примечания (сокращенные финансовые отчеты).

Организация финансового учета и формат представления финансовой отчетности согласно Закону о бухгалтерском учете Аолжны соответствовать требованиям, предусмотренным Аанным Законом и оАним из слеАующих стандартов: эстонский стандарт финансовой отчетности или межАународный стандарт финансовой отчетности, принятый Европейской комиссией в соответствии с процеАурой, установленной постановлением Европейского парламента № 1606/2002.

Основные принципы составления годовой отчетности установлены в ст. 16 Закона о бухгалтерском учете. Инструкция Службы бухгалтерского учета СБУ 1 «Общие принципы составления годового бухгалтерского отчета» ${ }^{12}$ подробно раскрывает суть каждого принципа и устанавливает правила их применения в годовых бухгалтерских отчетах.

Принятие Аирективы ЕC 2013/34/EU от 26 июня 2013 г. привело к принятию 24 ноября 2015 г. закона о переносе в Закон "О бухгалтерском учете» ${ }^{13}$ Болгарии новой Аирективы о бухгалтерском учете. Ст. 29 устанавливает, что годовой финансовый отчет Аля всех предприятий должен состоять по крайней мере из бухгалтерского баланса, отчета о прибылях и убытках и приложения. Стандарты бухгалтерского учета устанавливают форму и содержание полного комплекта финансовой отчетности.

Годовой финансовый отчет микропредприятий разрешено составлять только из сокращенного бухгалтерского баланса и сокращенного отчета о прибылях и убытках. При этом преАприятие может составлять и полный комплект финансовой отчетности.

Годовая бухгалтерская отчетность микропредприятий составляется на основе национальных стандартов бухгалтерского учета. Форма, структура и содержание компонентов финансовой отчетности общего назначения преАставлена в стандарте СС № 1 «ПреАставление финансовой отчетности" ${ }^{14}$. При этом закон "О бухгалтерском учете" разрешает преАприятию составлять годовую финансовую отчетность на основе международных стандартов бухгалтерского учета и МСФО (кредитные и финансовые учрежАения, страховщики, пенсионные компании, национальные инвестиционные фонды и др.).

В Чехии закон "О бухгалтерском учете» ${ }^{15}$ устанавливает требования к подготовке финансовой отчетности, вк^ючая применимые стандарты бухгалтерского учета и финансовой отчетности, ответственность за введение стандартов финансовой отчетности в Чешской Республике согласно закону несет Министерство финансов. Утвержденные Аля применения в ЕС МСФО необходимы Аля поАготовки финансовой отчетности компаний, чьи ценные бумаги торгуются на регулируемом рынке.

Финансовая отчетность предприятия включает бухгалтерский баланс, отчет о прибылях и убытках, приложение. Закон устанавливает, что предприятие может вести учет в упрощенном виле, если решение принимает учредитель и от преАприятия не требуется наличие финансовой отчетности, заверенной аудитором.

Микропредприятия не обязаны составлять отчет о Авижении денежных среАств и отчет об изменениях в капитале и не Аолжны раскрывать нефинансовую информацию в годовом отчете. Аля организаций, которые ведут учет по простой системе (без использования Авойной записи), формат отчета о доходах и расходах устанавливает Постановление

\footnotetext{
12 Инструкция Службы бухгалтерского учета СБУ 1 «Общие принципы составления годового бухгалтерского отчета". URL: https://www.rup.ee/rus/bukhgalterskii-uchet/estonskii-standart-finansovoi-otchetnosti.

${ }_{13}^{13}$ Закон за счетоводството. 502-01-64/29.07.2015. URL: https://www.lex.bg/bg/laws/ldoc/2136697598.

${ }^{14}$ CC № 1 - Представяне на финансови отчети / Национални счетоводни стандарти. URL: http://trudipravo. bg/znanie-za-vas/2015-08-31-09-52-20/natzionalni-standarti/870-ss-1-predstavyane-na-finansovi-otcheti.

${ }^{15}$ Zákon č. 563/1991/Sb. Zákon o účetnictví. URL: https://www.zakonyprolidi.cz/cs/1991-563.
} 
$325 / 2015^{16}$. Постановление 500/2002 $2^{17}$ Аля организаций, которые ведут учет в системе Авойной записи, регулирует объем и способ подготовки финансовой отчетности, устанавливает расположение и содержание статей финансовой отчетности, структуру и соАержание пояснительной и Аополнительной информации в примечаниях к финансовой отчетности.

Аля преАприятий, которые ведут бухгалтерский учет в соответствии с Постановлением 500/2002, выпущены чешские стандарты бухгалтерского учета Аля преАпринимателей.

В некоторых странах Европы основным нормативным правовым актом, закрепляющим основы формирования финансовой отчетности в стране, является кодекс: торговые кодексы в Германии и Франции, гражданские кодексы в Италии и Нидерландах, Кодекс компании в Бельгии.

В Германии согласно закону "О правовой модернизации баланса» ${ }^{18} 2009$ г. бухгалтерская финансовая отчетность является основой Аля расчета налогов немецких преАприятий. Это позволяет снизить аАминистративную нагрузку на национальные компании, предоставляя им возможность составлять еАиный пакет отчетности Аля бухгалтерского учета и налогообложения мибо ограничить необходимые корректировки Ао разумного минимума [Кабашкин В. А. и Ар., 2010].

Годовая отчетность Аолжна быть представлена балансом и отчетом о прибылях и убытках. Хозяйственные общества дополнительно обязаны составлять пояснения к гоАовому отчету, микропредприятиям разрешено составлять бухгалтерский баланс и отчет о прибылях и убытках в сокращенной форме. Также они освобожАаются от выполнения ряда общих требований, касающихся раскрытия информации, и могут не формировать пояснения и отчет руководства об основных результатах и перспективах Аеятельности [Козменкова С. В., Крупинова Е. С., 2015].

Во Франции принципы ведения бухгалтерского учета и составления финансовой отчетности основаны на Торговом кодексе, Плане счетов, а также Налоговом кодексе. МикропреАприятия подразделяются на Аве группы: занимающиеся торговой и неторговой Аеятельностью. Налоговый статус ^юбого микропредприятия проверяется и утвержАается налоговой инспекцией.

Согласно Торговому кодексу ${ }^{19}$ все физические и юридические лица, являющиеся преАпринимателями, Аолжны вести ежегодную отчетность и составлять отчет в конце финансового периода на основе бухгалтерских записей и инвентаризации. Такие годовые отчеты включают баланс, отчет о прибылях и убытках и приложение.

Общие и отраслевые требования к формированию финансовой отчетности устанавливаются уполномоченным органом по стандартизации учета и отчетности - Управлением по стандартам бухгалтерского учета (Autorité des Normes Comptables). В 2020 г. бы^ выпущен Сборник стандартов бухгалтерского учета Аля составления годовых отчетов промышленных и коммерческих преАприятий.

\footnotetext{
${ }^{16}$ Vyhláška 325/2015 Sb., ze dne 25. listopadu 2015, kterou se provádějí některá ustanovení zákona č. 563/ 1991 Sb., o účetnictví, ve znění pozdějších předpisů, pro účetní jednotky, které vedou jednoduché účetnictví. URL: https://www.noveaspi.cz/products/lawText/1/85146/1/2\#c_979.

${ }_{17}$ Vyhláška 500/2002 Sb. ze dne 6. listopadu 2002, kterou se prováději některá ustanovení zákona č. 563/ 1991 Sb., o účetnictví, ve zněni pozdějších předpisů, pro účetní jednotky, které jsou podnikateli účtujícími v soustavě podvojného účetnictví. URL: https://www.noveaspi.cz/products/lawText/1/54043/1/2.

${ }^{18}$ Gesetz zur Modernisierung des Bilanzrechts (Bilanzrechtsmodernisierungsgesetz - BilMoG). vom 25. Mai 2009. URL: https://www.bgbl.de/xaver/bgbl/start.xav?startbk=Bundesanzeiger_BGBI\&jumpTo=bgbl109s1102.pdf \#_bgbl_\%2F\%2F*\%5B\%40attr_id\%3D\%27bgbl109s1102.pdf\%27\%5D_1595863285189.

${ }_{19}$ Code de commerce. URL: https://www.legifrance.gouv.fr/affichCode.do;jsessionid=BDEAA77D4FA85AEOA5 5E2C17ADB17035.tplgfr28s_2?idSectionTA=LEGISCTA000006178754\&cidTexte $=$ LEGITEXTO00005634379\&date Texte $=20200811$.
} 
Италия придерживается общеевропейских требований к составлению финансовой отчетности, в соответствии с которыми она должна соответствовать межАународным стандартам. Полный комплект финансовой отчетности включает бухгалтерский баланс, отчет о прибылях и убытках и пояснительную записку, при этом Аля микропреАприятий годовая отчетность может иметь упрощенную форму.

Упрощения по подготовке финансовой отчетности микропреАприятиями были установмены Указом 139 от 18 августа 2015 г. ${ }^{20}$, в соответствии с которым микропредприятия имеют право, но не обязанность представлять финансовую отчетность в сокращенной форме, составленную в соответствии со ст. 2435 Гражданского кодекса Италии ${ }^{21}$, с преАставлением только бухгалтерского баланса и отчета о прибылях и убытках. Таким образом, микропреАприятия освобождаются от преАставления пояснительных записок и отчета руководства.

Сокращенная финансовая отчетность по структуре не отличается от полной формы, отмичие заключается в менее детализированном характере предоставления информации. Микропредприятия также имеют право представлять обычные годовые отчеты.

В Нидерландах Общие требования к составлению финансовой отчетности установлены разделом 9 ГражАанского кодекса 22 (с учетом Аирективы EC 2013/34/EU). Общая годовая финансовая отчетность включает: отчет совета управляющих, финансовую отчетность (бухгалтерский баланс, отчет о прибылях и убытках, примечания), прочую информацию.

Аля микроорганизаций предусмотрены некоторые исключения, относящиеся к подготовке и публикации финансовой отчетности, если они не готовят финансовую отчетность в соответствии с МСФО. Так, микроорганизации могут не составлять отчет совета управляющих и Аокументацию, относящуюся к прочей информации. Также Аля микроорганизаций нет требования обязательного подтверждения финансовой отчетности аудиторами, если они применяют общепринятые принципы бухгалтерского учета Нилерландов.

Финансовая отчетность микроорганизаций включает сокращенный баланс и сокращенные примечания. При подготовке годовой финансовой отчетности микроорганизация может ориентироваться на требования налоговых органов, чтобы не возникало различий межАу годовой финансовой отчетностью и налоговой декларацией. Как правило, это оценка по исторической стоимости, при которой основные среАства амортизируются. После составления годовой отчетности можно подавать налоговую декларацию вместе с годовой финансовой отчетностью.

Стандарты бухгалтерского учета Нилерландов основаны на четвертой Аирективе ЕС от 25 июля 1978 г. (78/660/ЕЕС). Выбор стандартов при ведении бухгалтерского учета и формировании финансовой отчетности также зависит от размера (типа) компании. Микроорганизации Аолжны выбрать между:

- книгой 2 ГражАанского кодекса Нидерландов в сочетании с принципами налоговой оценки;

- нилерландскими стандартами бухгалтерского учета Аля микро- и малых организаций;

- нилерландскими стандартами бухгалтерского учета Аля среАних и крупных организаций;

- международными стандартами финансовой отчетности (вк^ючая некоторые части ГражАанского колекса Нилерландов, разработанные в ниАерландских стандартах бухгалтерского учета Аля средних и крупных организаций).

\footnotetext{
${ }^{20}$ Decreto Legislativo 18 agosto 2015, n. 139. URL: https://www.gazzettaufficiale.it/eli/id/2015/09/04/ $15 \mathrm{G} 00153 / \mathrm{sg}$.

${ }^{21}$ Codice civile (R.D. 16 marzo 1942, n. 262). URL: https://www.brocardi.it/codice-civile/libro-quinto/titolo-v/ capo-v/sezione-ix/art2435bis.html.

${ }^{22}$ Burgerlijk Wetboek Boek2. URL: https://wetten.overheid.nl/BWBR0003045/2020-07-08\#Boek2_Titeldeel9_ Afdeling11_Artikel395a.
} 
Компании, чьи акции котируются на бирже, вне независимости от размера Аолжны использовать международные стандарты финансовой отчетности в сочетании с нилерланАскими стандартами бухгалтерского учета Аля среАних и крупных организаций.

Микро-, малые и крупные предприятия Бельгии Аолжны вести полный комплект бухгалтерских книг (бухгалтерский учет с Авойной записью) в соответствии с установленным законом планом счетов (ст. III.84 Кодекса преАпринимательской деятельности и экономического права $)^{23}$.

В соответствии с королевским указом от 29 апреля 2019 г. бельгийские общепринятые принципы бухгалтерского учета Аолжны применяться всеми компаниями при составлении годовой отчетности. Применение МСФО или Аругих стандартов не Аопускается. Стандарты МСФО применяются только при составлении консолиАированной финансовой отчетности компаний, чьи ценные бумаги торгуются на регулируемом рынке.

Все компании обязаны подавать годовую финансовую отчетность (баланс, отчет о прибылях и убытках, примечания к финансовой отчетности, краткое изложение принципов бухгалтерского учета, список членов правления) в соответствии с заранее определенным форматом, установленным Центральным бухгалтерским управлением.

Кодекс также устанавливает, что микрокомпании могут составлять годовые отчеты в соответствии с микромоделью, установленной королем. Микромодель Аля микрокомпаний состоит из баланса и отчета о прибылях и убытках, а также приложения, которое по объему меньше, чем применяемое к малым компаниям. При этом компании обязаны составлять социальный баланс по той же сокращенной схеме, что и другие малые преАприятия. Микрокомпании освобожАены от необходимости составлять управленческие отчеты, если они не зарегистрированы на бирже.

Отдельного внимания заслуживает опыт Португалии и Греции. В отличие от рассмотренных выше стран в Португалии система финансовой отчетности микропредприятий является многоуровневой, основные принципы закреплены в Законе о коммерческих компаниях и подробно рассмотрены в стандартах. Финансовая отчетность микроорганизаций в Греции также многоуровневая, но имеет существенные различия в зависимости от типа организации - законодательно закреплено Ава типа микроорганизаций.

Так, Португалия в части составления финансовой отчетности подчиняется требованиям, установленным в постановлениях и директивах ЕС, перенесенных в национальные законы и постановления. Закон № 98/2015 «О коммерческих компаниях" ${ }^{24}$ устанавливает основные принципы и правила составления финансовой отчетности Аля всех хозяйствующих субъектов и требует от компаний ведения бухгалтерских Книг и поАготовки гоАовой финансовой отчетности.

Закон № 134/2012 25 закрепляет полномочия Комитета по стандартизации бухгалтерского учета, находящегося в ведении Министерства финансов, в сфере разработки станАартов бухгалтерского учета Аля преАприятий корпоративного и государственного секторов.

Закон № 35/2010 устанавливает применение упрощенных правил бухгалтерского учета и финансовой отчетности Аля микроорганизаций и также позволяет им применять правила бухгалтерского учета, предусмотренные Законом № 158/2009.

Микроорганизации Аолжны составлять следующие виды отчетов: бухгалтерский баланс, отчет о прибылях и убытках, приложение. В соответствии со стандартом бухгалтерского учета Аля микропреАприятий они освобожАены от обязанности преАставлять

\footnotetext{
${ }^{23}$ Wetboek van Economisch Recht (Frans: Code de droit économique). URL: https://docplayer.nl/427557Wetboek-van-economisch-recht-boek-iii.html.

${ }^{24}$ Decreto-Lei $n .^{\circ}$ 262/86. Código das Sociedades Comerciais. URL: https://dre.pt/web/guest/legislacaoconsolidada/-/Ic/view?cid=116042191.

${ }^{25}$ Decreto-Lei n. ${ }^{134 / 2012}$ de 29 de junho. URL: http://www.cnc.min-financas.pt/pdf/DL_134_2012_29_ Junho.pdf.
} 
отчеты о Авижении денежных среАств и об изменениях в капитале. Формы финансовой отчетности Аля микроорганизаций установлены постановлением № 104/2011 от 14 марта.

В целом стандартизация финансовой отчетности микропреАприятий в Португалии включает следующие элементы:

1) основа Аля преАставления финансовой отчетности микропреАприятий (BADF-ME) глобальные требования Аля обеспечения сопоставимости как с финансовой отчетностью за преАыдущие периоды той же организации, так и с финансовой отчетностью Аругих организаций;

2) шаблоны финансовой отчетности Аля микропредприятий (MDF-ME) - формы бухгалтерского баланса, отчета о прибылях и убытках и приложения;

3) коды (номера) счетов бухгалтерского учета Аля микропредприятий (СС-ME), которые публикуются распоряжением члена правительства, ответственного за сферу финансов, и содержат сводный план счетов, коды счетов (кодифицированный список счетов) и справочную информацию;

4) стандарт бухга^терского учета А^я микропреАприятий (NC-ME);

5) нормативные правила толкования Аля микропредприятий (NI-ME), выпускаются при необходимости преАоставления разъяснений к стандарту.

Греческое законодательство о бухгалтерском учете и финансовой отчетности в значительной степени соответствует законодательству Европейского союза. Аиректива Европейского союза 2013/34/ЕС была перенесена в национальное законодательство.

Закон 4308/2014 устанавливает, что структура и содержание финансовой отчетности, подготовленной организациями, различаются в зависимости от типа микроорганизаций. $\mathrm{K}$ первому типу относятся организации, которые на дату составления баланса не превышают лимитов минимум по Авум из слеАующих трех критериев:

- итого по балансу: 350 тыс. евро,

- чистый оборот: 700 тыс. евро,

- среднее количество сотруаников в течение отчетного периода: 10.

При этом если у организации среАнее количество сотрудников за отчетный периоА составляет 10 человек и размер оборота не превышает сумму 1,5 м^н евро, оно попаАает в категорию микроорганизаций второго типа.

Согласно ст. 16 закона финансовая отчетность микроорганизации Аолжна включать балансовый отчет или отчет о финансовом положении, отчет о прибылях и убытках, примечания к отчету. В качестве альтернативы микроорганизации могут выбрать подготовку финансовой отчетности в соответствии с сокращенным форматом баланса, сокращенным форматом отчета о прибылях и убытках.

Микроорганизации второго типа также могут, приняв во внимание необходимости соблюдения Аругого законодательства, подготовить только сокращенный отчет о прибылях и убытках.

\section{ФИНАНСОВАЯ ОТЧЕТНОСТЬ В ВЕАИКОБРИТАНИИ}

В Великобритании микропредприятие обязано формировать отчетность, содержащую следующие элементы:

- балансовый отчет;

- отчет Аиректоров предприятия;

- отчет о прибылях и убытках;

- аудиторское заключение, за исключением случаев, когда компания освобождается от аудита (если предприятие соответствует установленным критериям, оно может преАставить неаудированную отчетность);

- примечания к отчетам [Gov.uk, 2019]. 
Закон 2013 г. о малых компаниях Великобритании (SI 2013/3008)26 преАоставил новую систему отчетности Аля британских компаний, которые отвечают квалификационным критериям микропреАприятия. Согласно указанному закону микропреАприятия могут использовать упрощенные форматы Аля бухгалтерского баланса и отчета о прибылях и убытках и обязаны предоставлять только примечания к финансовой отчетности, касающиеся гарантий и Аругих финансовых обязательств. Подобный режим Аля микропреАприятий является необязательным в Великобритании, но микропредприятие, которое решает поАготовить свою финансовую отчетность в соответствии с ним, Аолжно применять стандарт финансовой отчетности Аля микропреАприятий FRS 105.

МикропреАприятия, которым не разрешено применять режим упрощенной отчетности (например, благотворительные организации), могут подготовить финансовую отчетность в соответствии с требованиями раздела 1А "Малые преАприятия" стандартов финансовой отчетности, применяемых в Великобритании и Ирландской Республике (FRS 102) [Козменкова С. В., Крупинова Е. С., 2015].

Если преАприятие составляет консолидированную отчетность, то ее подготовка Аолжна осуществляться в соответствии с требованиями стандартов финансовой отчетности, применяемых в Великобритании и Ирландской Республике (FRS 102).

\section{ФИНАНСОВАЯ ОТЧЕТНОСТЬ В РОССИЙСКОЙ ФЕАЕРАЦИИ}

В Российской Федерации Федеральный закон "О бухгалтерском учете» ${ }^{27}$ устанавливает обязанность экономического субъекта вести бухгалтерский учет. Согласно п. 1 ч. 4 ст. 6 этого закона субъекты малого предпринимательства могут применять упрощенные способы ведения бухгалтерского учета, вк^ючая упрощенную бухгалтерскую (финансовую) отчетность. В то же время решение о форме финансовой отчетности - общем или упрощенном порядке - принимается организацией самостоятельно и закрепляется в учетной политике согласно письму Минфина РФ от 11.02.2016 № 07-01-10/729728.

В информации Министерства финансов Российской Федерации "Об упрощенной системе бухгалтерского учета и бухгалтерской отчетности" ${ }^{29}$ поясняется, что если организация применяет упрощенные способы, то она может составлять сокращенную финансовую отчетность. Организация при составлении упрощенной годовой финансовой отчетности может разрабатывать формы финансовой отчетности самостоятельно.

Положение по бухгалтерскому учету "Бухгалтерская отчетность организации" ПБУ 4/9930 устанавливает общие требования к составу бухгалтерской отчетности, в том числе к содержанию бухгалтерского баланса и отчета о прибылях и убытках.

Приказ Министерства финансов Российской Федерации "О формах бухгалтерской отчетности организаций» ${ }^{31}$ устанавливает состав и содержание бухгалтерской отчетности - бухгалтерского баланса, отчета о финансовых результатах, отчета об изменениях

\footnotetext{
${ }^{26}$ The Small Companies (Micro-Entities' Accounts) Regulations 2013. URL: https://www.legislation.gov.uk/ uksi/2013/3008/contents.

27 Федеральный закон от 06.12.2011 № 402-Ф3 “О бухгалтерском учете». URL: https://normativ.kontur.ru/ document?moduleid=1\&documentid=351729\#I327.

${ }^{28}$ Письмо Минфина России от 11.02.2016 № 07-01-10/7297. URL: https://www.garant.ru/products/ipo/ prime/doc/71262840/.

${ }^{29}$ Информация Министерства финансов Российской Федерации от 29 июня 2016 г. № П3-3/2016 "Об упрощенной системе бухгалтерского учета и бухгалтерской отчетности". URL: https://normativ.kontur.ru/document? moduleid $=1 \&$ documentid $=277288 \#$ h75.

30 Положение по бухгалтерскому учету “Бухгалтерская отчетность организации" ПБУ 4/99 (утв. приказом Минфина РФ от 6 июля 1999 г. № 43н). URL: http://ivo.garant.ru/\#/document/12116599/paragraph/46:0.

31 Приказ Министерства финансов Российской Федерации от 2 июля 2010 г. № 66н "О формах бухгалтерской отчетности организаций". URL: https://normativ.kontur.ru/document?moduleld=1\&document/d=336238\#h200.
} 
капитала и отчета о Авижении денежных средств, а также формы упрощенной бухгалтерской отчетности, при которой в бухгалтерском балансе, отчете о финансовых результатах, отчете о целевом использовании среАств не применяется детализация показателей по статьям, а в приложениях к бухгалтерской отчетности приводится только наиболее важная информация.

Приказ Министерства финансов Российской Федерации “Об утверждении положений по бухгалтерскому учету" "22 предоставил право микропредприятиям, которые составляют упрощенную финансовую отчетность, вести бухгалтерский учет по простой системе (без применения Авойной записи).

\section{ВЫВОАЫ}

Анализ законодательства, проведенный в рамках данного исследования, показал, что обязанность вести бухгалтерский учет и формировать финансовую отчетность установлена во всех государствах. При этом в большинстве стран предусмотрена упрощенная система отчетности Аля микропреАприятий.

В некоторых странах, например в Эстонии, микроорганизации могут выбрать, на основе каких стандартов формировать финансовую отчетность - национальных или МСФО. Некоторые страны Аопускают применение МСФО только Аля опреАеленного типа компаний, например чьи акции торгуются на рынке (Бельгия, Чехия).

В Германии, Нидерландах и Беларуси при формировании финансовой отчетности микроорганизации ориентируются на требования налоговых органов, что значительно упрощает систему формирования документов и позволяет готовить единый пакет отчетности.

Проведенное исследование показало наличие в большинстве стран национальных станАартов, позволяющих микроорганизациям формировать отчетность в сокращенном порялке, тем самым снижая нагрузку на бухгалтерию и расходы на осуществление управленческой деятельности. Это позволяет им улучшить экономические показатели организации и более устойчиво чувствовать себя на рынке.

В Российской Федерации существует проблема правовой нестабильности, когАа в закон часто вносятся изменения, а также принимаются дополнительные письма и инструкции, призванные предоставить разъяснения по применению законодательных норм. По факту многие микроорганизации не успевают отследить внесенные изменения и, соответственно, проверить уровень выполнения требований, установленных законодательством. Такая ситуация приводит к штрафам, блокировке счетов и прекращению деятельности.

Несмотря на значительную поддержку государства сектора малого и среднего преАпринимательства, количество микроорганизаций в России продолжает сокращаться. При этом межАународный опыт показывает, что микроорганизации, в большинстве преАставленные семейным бизнесом, являются наиболее стабильными и ориентированными на Аолгосрочное развитие.

Опыт ряда зарубежных стран показывает, что следующим эффективным шагом может стать применение особых режимов налогообложения и формирования налоговой отчетности Аля микроорганизаций, увязанной с финансовой отчетностью. Это позволит снизить нагрузку на бухгалтера, слелать процесс формирования отчетности более простым.

В настоящее время Фелеральная налоговая служба изучает различные варианты формирования новой концепции налогообложения Аля малых и микропредприятий. ОАин из вариантов - исчислением налога будет заниматься Федеральная налоговая служба, тогАа вести бухгалтерский и налоговый учет и саавать декларации будет не надо.

\footnotetext{
32 Приказ Министерства финансов Российской Федерации от 6 октября 2008 г. № 106н “Об утверждении положений по бухгалтерскому учету". URL: http://docs.cntd.ru/document/902126008.
} 
Таким образом, снижение налоговой нагрузки, упрощение системы финансовой отчетности, оказание различных виАов подАержки - все это будет способствовать устойчивому развитию микроорганизаций, тем самым внося весомый вклаА в укрепление экономики страны.

\section{Список источников}

Кабашкин В. А., Аубровская О. И., Аузгина Е. И. Основы организации и особенности бухгалтерского учета в Германии // Международный бухгалтерский учет. 2010. № 5 (137). С. 43-49.

Козменкова С. В., Крупинова Е. С. Упрощенные правила бухгалтерского учета и отчетности Аля малых и среАних предприятий в зарубежной практике // Международный бухгалтерский учет. 2015. № 40 (382). С. 34-52.

Company House Accounts Guidance. Updated 6 September 2019 / Gov.uk. URL: https://www.gov.uk/government/ publications/life-of-a-company-annual-requirements/life-of-a-company-part-1-accounts\#micro-entity-accounts.

Comprehensive review of the IFRS for SMEs / IFRS, 2015. URL: https://www.ifrs.org/supporting-implementation/ supporting-materials-for-the-ifrs-for-smes/\#about.

Guidance for micro-sized entities. International Accounting Standards Board / IFRS, 2013. URL: https://www.ifrs. org/supporting-implementation/supporting-materials-for-the-ifrs-for-smes/micros/.

\section{References}

Gov.uk (2019). Company House accounts guidance. Updated 6 September. Available at: https://www.gov.uk/ government/publications/life-of-a-company-annual-requirements/life-of-a-company-part-1-accounts\#micro-entityaccounts/.

IFRS (2013). Guidance for micro-sized entities. International Accounting Standards Board. 2013. Available at: https://www.ifrs.org/supporting-implementation/supporting-materials-for-the-ifrs-for-smes/micros/.

IFRS (2015). Comprehensive review of the IFRS for SMEs. Available at: URL: https://www.ifrs.org/projects/ completed-projects/2015/2015-comprehensive-review-of-the-ifrs-for-smes/.

Kabashkin V.A., Dubrovskaya O.I., Luzgina E.I. (2010). Basics of Organization and Features of Accounting in Germany. Mezhdunarodnyj bukhgalterskij uchet - International Accounting, no. 5 (137). pp. 43-49.

Kozmenkova S.V., Krupinova E.S. (2015). Simplified Accounting and Reporting Rules for Small and Medium-sized Enterprises in Foreign Practice. Mezhdunarodnyi bukhgalterskii uchet - International Accounting, no. 40 (382), pp. 34-52.

\section{Информация об авторе}

Наталья Сергеевна Матвеева, младший научный сотрудник Центра финансового менеджмента в государственном секторе Научно-исследовательского финансового института Минфина России, г. Москва

\section{Information about the author}

Natalia S. Matveeva, Junior Researcher, Center for Financial Management in the Public Sector, Financial Research Institute, Moscow

Статья поступила в редакцию 21.06.2021

ОАобрена после рецензирования 30.09.2021

Принята к публикации 15.10.2021

Article submitted June 21, 2021

Approved after reviewing September 30, 2021 Accepted for publication October 15, 2021 